\title{
Podstawy teoretyczne projektowania sztucznego oświetlenia w ujęciu architektonicznym
}

\section{The basics of theoretical design of artificial illumination in an architectural point of view}

\begin{abstract}
Streszczenie
Artykuł omawia problematykę podstaw projektowania sztucznego oświetlenia w ujęciu architektonicznym, w nawiązaniu do wymagań z zakresu techniki oświetleniowej i elektrycznej. Przedstawiono zbiór teoretycznych aspektów tego zagadnienia, mogących wpływać na kształtowanie projektów oświetleniowych dzieł architektonicznych, z uwzględnieniem zasad kompozycji i funkcjonalności architektury. Dyskusji poddano także oddziaływanie sztucznego oświetlenia na postrzeganie przestrzeni architektonicznej przez użytkownika.
\end{abstract}

\begin{abstract}
The article discusses the problems of designing an artificial illumination from an architectural point of view, in connection with the requirements of lighting and electrical engineering. A set of theoretical aspects of this issue, which may influence the design of architectural lighting projects, is presented, taking into account the principles of composition and functionality of architecture. The interaction of artificial lighting has also been discussed for the perception of the architectural space by the user.
\end{abstract}

Słowa kluczowe: światło w architekturze, teoria projektowania światła, reguły, sztuczne oświetlenie, światło Keywords: light in architecture, arificial illumination, theory of light design, rules, light

Peter Zumthor, zapytany podczas jednej ze swoich rozmów z Mario Nannim ${ }^{1}$, czym jest dla niego światło, odpowiedział - „Ile światła potrzebuje człowiek i ile ciemności? Trzy myśli, bardziej niż jakiekolwiek inne poruszają moją duszę. 1 - zasada życia, cud rzeczy organicznych, 2 - ludzkie emocje, zdolność istoty ludzkiej do entuzjazmu, błogosławieństwo inteligencji i świadomości, 3 - światło, naturalne światło, które ożywa w jego subtelności, nigdy takie samo, od Słońca do cienia i z ciemności do zmierzchu oraz sztucznego światła, zaprojektowanego w sposób szczegółowy, by oddawać charakter przestrzeni bez narzucania się."2 Ten filozoficzny przykład myślenia o sposobie projektowania sztucznego oświetlenia obiektów architektonicznych i przestrzeni urbanistycznych jest niejako kontynuacją postaw teoretyków modernizmu. Już Erich Mendelshon określał światło nie tylko jako kolejny instrument do projektowania dla architekta ale również jako element należący do emocjonalnej strony sztuki ${ }^{3}$. Wszystkie teoretyczne rozważania dotyczące projektowania i zastosowania sztucznego oświetlenia, szczególnie pojawiające się w XX w. oraz współczesne postawy dotyczące tego aspektu sztuki architektonicznej, można przypisać do dwóch kategorii - z jednej strony światło wykorzystywane w sposób pośredni, jako odtwarzacz architektury, z drugiej zaś jako jej kreator. Te sposoby myślenia przewijają się we współczesnym myśleniu o projektowaniu sztucznej iluminacji .
Peter Zumthor was asked by Mario Nanni' during one of his talks, "what is light for you?", he answered; "How much light and how much darkness does a human need? Three thoughts, more than anything, move my soul. 1 - The rule of life, the miracle of organic things, 2 - human emotion, the human ability to express enthusiasm, the blessing of intelligence and consciousness, 3 - light, natural light that revives you in its' subtleness, never the same, from the sun to the shade and from the darkness to the sunrise as well as artificial light, designed in an intricate way to express the space but not to enforce itself upon it" ${ }^{\prime \prime}$. This philosophical example of thinking about designing artificial light in architectural objects and urban spaces is a continuation of the fundamental concepts of modernism. Even Erich Mendelshon described light not only as another instrument for an architect to use when designing, but an emotional element relating to the formation of $\mathrm{art}^{3}$. All theoretical reflections on the design and use of artificial lighting, particularly in the $20^{\text {th }}$ century and the contemporary attitudes to this aspect of architectural art, can be attributed to two categories - on the one hand indirectly used as an architectural player and on the other as its creator. These ways of thinking are reflected in modern thinking about artificial illumination ${ }^{4}$. 
Czym zatem jest światło? Odpowiedź zawsze zależy od tego, do kogo kierowane jest pytanie. M. Nanni pisze - każda forma twórczej ekspresji ma swoje dominujacce znaczenie - malarstwo wyraża się kolorem, rzeżba przez przestrzeń, taniec przez rytm, fotografia świattem, architektura zaś przez wszystkie te znaczenia ${ }^{5}$ To, o czym zapominamy, choć w naszej podświadomości jest stale obecne, to indywidualne preziywie swata. Dla projeklanta swa przez nu emoci obiekl i prze Drze Kreaci, kora przezy wac bęzle kazdy

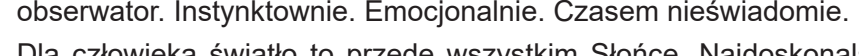
Dla czloweka swillo to przede wazyskim Slonce. Najdoskonalsze światto. Regulator rytmu życia. Życia każdego organizmu na Ziemi. Dzięki niemu odczuwamy emocje ale również obserwujemy i zapamiętujemy otaczający nas świat. W architekturze jest podstawą kreacji. Używamy nawet określenia „zobaczyć coś w innym świetle”. Nie wypada nawet nie przytoczyć słynnego dogmatu Le Corbusiera - „architektura to mądra skorygowana gra brył w świette"6, odnoszącego się właśnie do światta słonecznego. Rozwój technologiczny daje nam możliwość kreowania sztucznego oświetlenia, które nawiazuje do światta naturalnego. Choć jeszcze niedoskonale.

Niemniej jednak, próbując określić fundamenty teorii w zakresie projektowania sztucznego oświetlenia, nie można zapomnieć także o tym aspekcie. Sztuczne światto to namiastka Słońca wniesiona do naszego otoczenia. Nie można go w sposób oczywisty przenieść wprost lecz interpretować jego działanie. Światto jest widoczne, światto pracuje, służy do kontemplacji i podziwiania, wywołuje emocje ale jest także zmienne, intensywne i dyskretne, porusza się. Jest wymierne gdy mówimy o architekturze, możemy je sprowadzic do całek, zmierzyć natężenie. Powstaje jednakże pytanie, czy rozważania teoretyczne, oparte w zasadzie na - $z$ jednaj strony - emocjonalnym $i$ intuicyjnym rozważaniu roli jaką niesie sztuczna iluminacja, a $z$ drugiej strony widziane jako elektrotechnika, domena projektantów instalacij elektrycznych, sztywrozwiazań głównie normatywnych, stanowia wystarczajaca podstawe projektomania sztucznej ilumi projektowanias zmuifora postrzega się dzis zagadnienie wprowadzana szlucza go oswietlenia w przestrzeń architektoniczna. Intuicyjność, emocjonalność, duchowość oraz zmienność światta połączone z rozbudowaną czysto inżynierską stroną projektowania sztucznego oświettenia, stanowią wysoce skomplikowany aspekt sztuki architektonicznej. Z jednej strony wymagany we współczesnym środowisku architektonicznym, z drugiej nie wystarczająco poznany aspekt.

Jedną z fundamentalnych zasad jest stosowanie światta tylko tam gdzie jest ono potrzebne. Bez względu na to czy rola światta beedzie

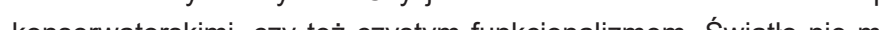
zapehilać niepotrzebnie przestrzeni. Jego rolą jest wydobywanie ja-

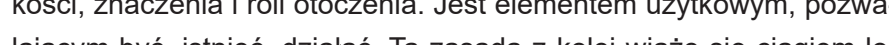
lającym byc, istniec, dzlalac. Ta zasada z kolei wiaze się ciagiem logicznym z koniecznością dbałości o miejsca nieoświetlone. Pochwała cienia. Światto i cień to jedno. Tworząc swiatto tworzymy cień. Cien domyka naszą opowieść świattem. Cień dodaje tajemniczości, podkresla swiatio. Kreując oświetlenie, kreujmy przestrzeñ bez swiatia. Świadomie. Cień to atawistyczna część natury człowieka. Ta niespokojna, przepełniona lękiem część duszy. Ty bardziej podnosząca war-
Then what is light? The answer always depends on who whe question is dicected to. M. Nanin writes 'every form of artistic expression has its' dominating meaning - paintic exs express has is' do using but architecture uses all of these methods" 5 . This, whether or not we forget, although in our subconscious is constantly present, is the individual experiencing the light. For an architect, ligh is a tool to convey the emotion of the object and area. It should be a creation that every observan Sometimes unknowingly.

For a human being, light us most importantly the sun. The perfect light. Rhythm regulator of life. The life of every organism on Earth. Thanks to it we experience emotion and also observe and remember the world around us. In architecture it is the basis of in new. light". It is only right if we add the famous phrase by Le Corbusier "Architecture is an intelligen game of cubes in the light", referring to the sunlight. The development of new technologies allows us to expand the limits of artificial lighting, which replicates natural light. Although still not perfect. Nevertheless, in trying to determine the foundaforget of this aspect. Artificial light is a substitute for the sun brought into our environment. It can not be easily transposed but interpreted. Light is visible, light works, it is used for the contemplation and admiration, brings out emotion but also chang es, becomes intensive and discreet, it moves. It is can bring it to the integrals, measure the intensity. However, a question arises, do the theoretical considerations essentially based on - on one hand the emotional and intuitional consideration of the role that artificial illumination plays, and from the other hand seen as electro toch cal installations, igidly holding onto usually normatheories in the field of designing artificial illumination. It seems that the aspect of functionalism and the engineering form of this issue have dominated the way in which today the question of introducing artificia lighting into the architectural space is perceived. Intuition, emotionality, spirituality, and variability of
light combined with the elaborate engineering side of artificial lighting design constitute a highly complex aspect of architectural art. On the one hand, it is required in today's architectural environment, on the other hand not sufficiently known aspect.

One of the fundamental principles is to use light the role of light will be restogative or creative, is imposed with requirements - for orample, is vational ones - or is it pure functionalism? Light is not supposed to fill unnecessary spaces. Its' role is extracting the quality, meaning and role of the surroundings. It is an element of usage, allowing us to be, exist and work. This rule is, however, logically entangled with the necessity of looking after unl areas. The praise of the shadow. Light and shade
is one thing. Creating light we create shade. The shadow closes our story with light. The shadow adds mysteriousness, highlights the light. Creating lighting, we also create unlit spaces. Consciously.

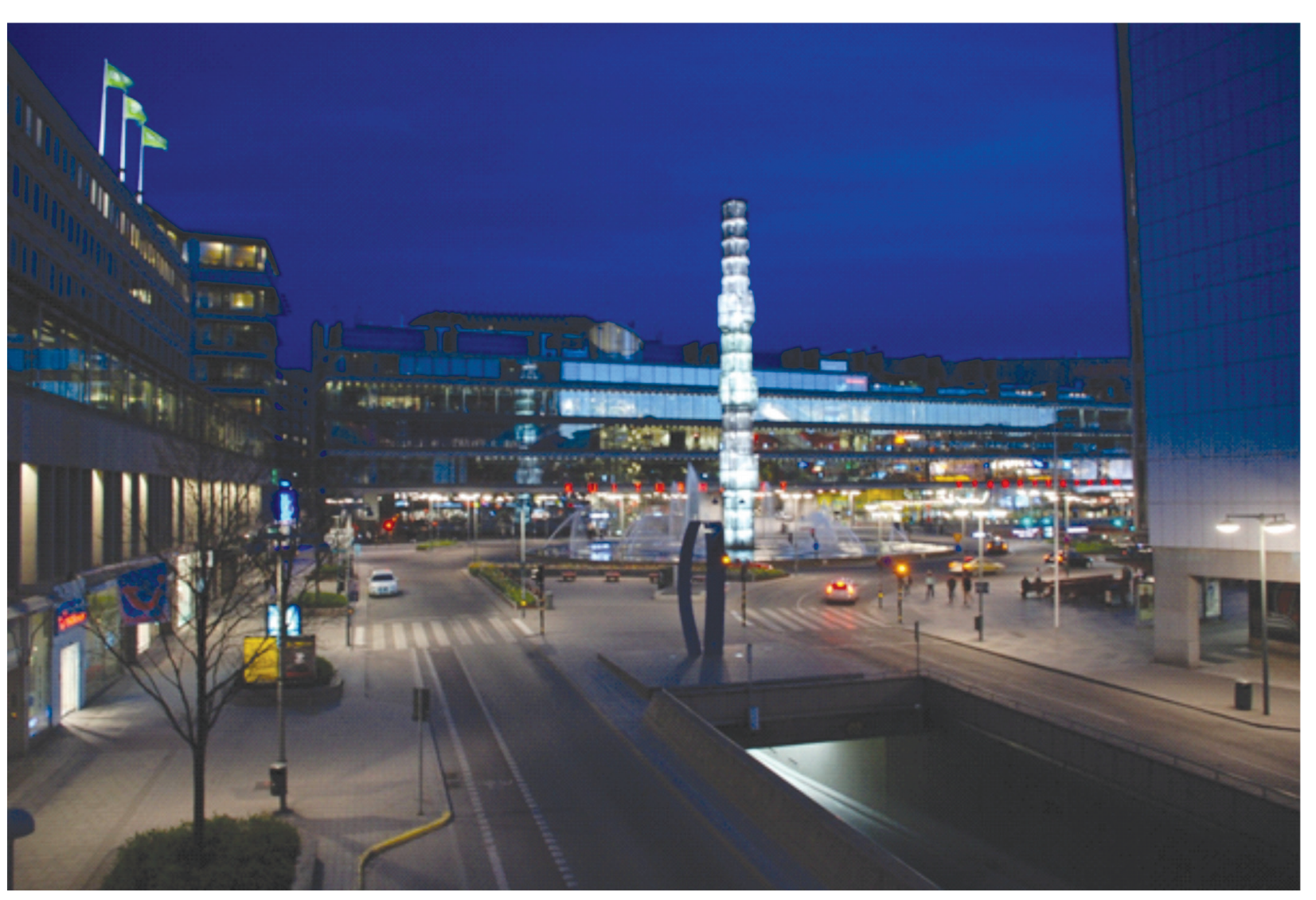

IV. 1. Sergels torg, Sztokholm, Szwecja, fot. M. Kowalski / Sergels Torg, Stockholm, Sweden, Pict. M. Kowalski

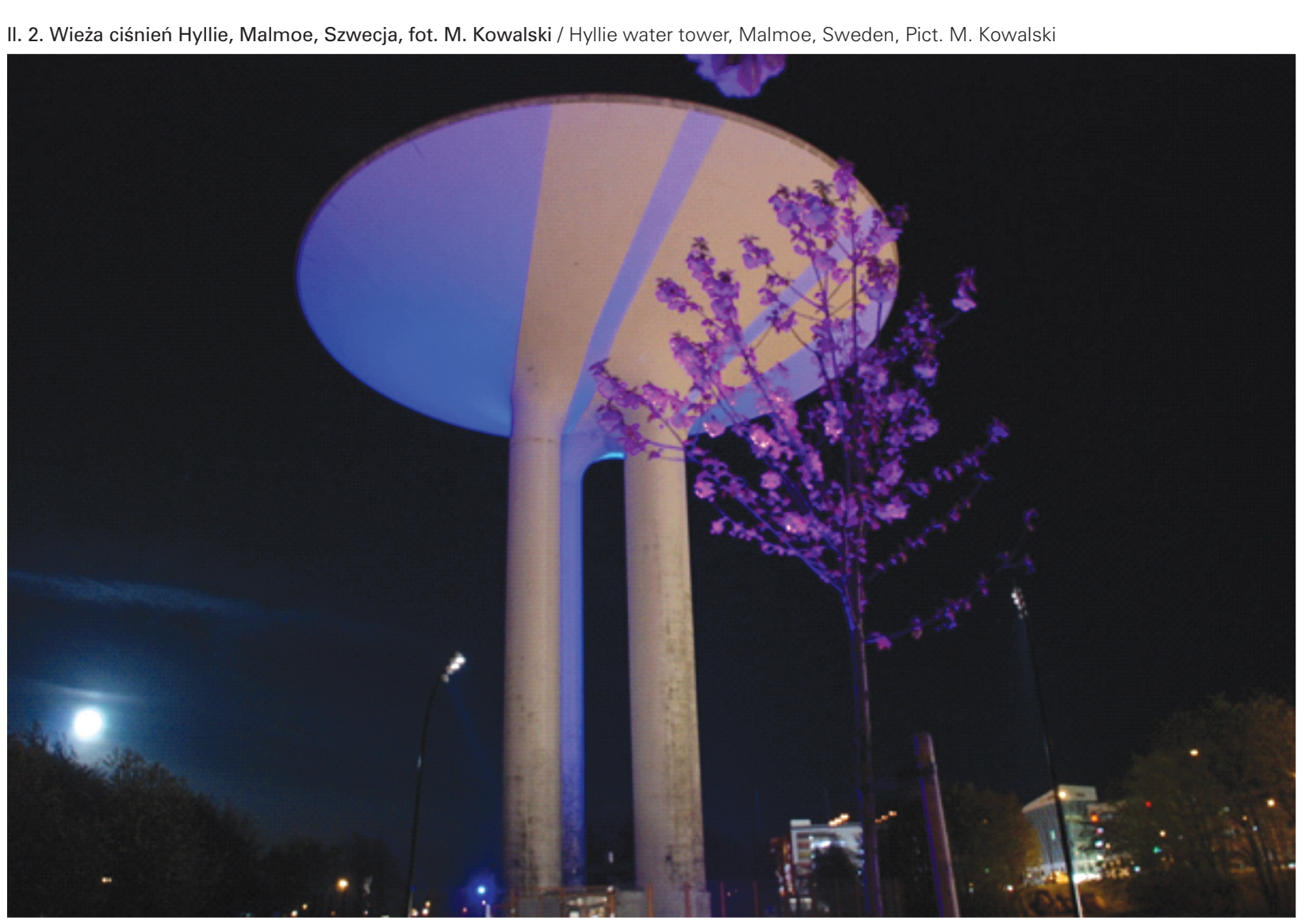


tość przestrzeni jasnej, pełnej poczucia bezpieczeństwa i swobody. W świecie zdominowanym przez funkcjonalizm, cień bez nadmiernych kontrastów, bez martwych pól.

Niejako pomiędzy tymi zasadami, łącząc je i spajając, światto jest obecne i nieobecne. Dla architekta to być może podstawowa zasada ale i trudność. Projektować światto tak aby nie widać było źródeł światta. Aby jedynie jego emanacja zaznaczała swoja obecność A techniczne aspekty, formy, obiekty, sa ukryte, poza zasiegiem wzroku obserwatora. Z jednej strony by nie narzucać swej obecności w odbiorze przestrzeni, $z$ drugiej zaś by nie oślepiać, by nie zmieniać formy obiektu i przestrzeni architektonicznej. I tu pojawić się winna kolejna zasada, czy też możliwość jej zastosowania. Czy światto nie powinno zatem stanowić integralnej części architektury? Dosłownie i w przenośni - być jej materiałem konstrukcyjnym? Architekt nie tylko stara się ukryc zrodło swiatta, ale także sprawic, by forma jego obudowy wtopiła się w sposób doskonały w przestrzeń. Scalenie struktur, pełna integracja fizyczna. Oczywistym jest tu fakt, że w tym wypadku niezwykle silnie teoria miesza się $z$ praktycznym zastosowaniem materiałów, form stricte inżynierskich.

Plama światta, jej ksztalt, forma, grubość, wielkość. To elementy kompozycyjne, powszechnie stosowane, głownie w najpowszechniejszej eliptycznej bąź sferycznej formie. Działanie plama światła przypomina teatralne , wskazujące i punktujące rozwiazzania." Oto najważniejszy element! Widzu skup się na nim!", zdają się wręcz krzyczeć. kości, pod względem technicznym nie jest skomplikowane. Warto tu zwrócic uwagę na liczne możilwości stosowania fitrów i soczewkowania lub samego ksztaltowania oprawy oświetleniowej. Celem ostatecznym jest efekt przestrzenny, jaki możliwy jest do uzyskania w danej przestrzeni

I wreszcie kolor. Podobnie jak promienie Stońca generują kolor, tak i stosowanie wartości fizycznych różnorakich żródeł światta jest wykorzystywane przy kreacii projektów oświetleniowych. Jest to kolejna zasada w której wydźwięck teoretyczny zawiera w sobie dużą dawkę wiedzy czysto praktycznej, inżynierskiej. W tym wypadku z zakresu techniki świetlnej dotyczącej fizycznych właściwości różnorakich źródeł światta w szczególności żródel światta LED. $Z$ uwagi na ich coraz powszechniejsze zastosowanie i co za tym idzie ich wpływ na środowisko, oddziaływanie na nie i przebywającego $\mathrm{w}$ nim obserwatora. Dotyczy to także budowy oprawy i zastosowania filtrów barwnych. Kolor jest także nośnikiem emocji, pobudza jak i uspokaja. Kolor determinuje postrzeganie i odbiór otoczenia. Działanie barwą światta może podkreślać, ukrywać bądź zmieniać przestrzen.

Podażając za aspektem fizycznych właściwości światta słonecznego, nie sposób zapomnieć ìz światto słoneczne to ruch. Zmienność. Wpływ moga tu mieć czynniki geograficzne, klimatyczne, pora roku. Ruch powoduje zmianę koloru, odbioru formy i przestrzeni. Zmienny jest kierunek padania, intensywność, natężenie, temperatura barwowa. Ale ruch światta słonecznego to przemieszczenie żródła światta. Podobnie jak w przypadku koloru, i tutaj światto w ruchu pojawia się w zakresie projektowania sztucznego oświetlenia. Jednakże jest to w sensie ściśle związanym z architekturą, raczej kwestia albo iluminacji dynamicznej, czyli okazjonalnych spektakli swietinych lub zintegrowanych z budynkami systemów multimedialnych nośników informacji. Problematykę tę można rozpatrywać także jako ruch materii oświetla-
The shade is an atavistic element of human nature. That restless, fear - filled part of the soul. Tha more uplitting value of an illuminated space, filled with a feeling of safety and freedom. In a world
dominated by functionalism, the shadow without excessive contrasts, without dead fields.

In some measure between these rules, joining and bonding them, light is present and absent. For an architect this could either be a fundamental principle or a difficulty. To design light as to not depic its' source. So that only its' emanation highlights its' presence. Yet its' technical aspects, forms, objects side to not impose its' presence in the perception of the space, on the other not to dazzle, to not chang the form of the object and architectural space. And here another rule should be put in place, or the abiity of applying it. Shouldn't light then become an integral element of architecture? Literally and figura
tively - become its' building material? The archite not only tries to hide the light source, but also to make the form of its enclosure melt perfectly into space. A merger of structures, full physical integration. It is an obvious fact here that, in this case theory strongly mixes with the practical use of materials, strictly in engineering concepts.

The stain of light, its' shape, form, thickness, size. These are compositional elements, widely used
mainly in the most common elliptical or spherica form. The use of the stain of light brings to mind theatrical, indicative and pointing solutions. "Here is the most important element! Spectator, focus on it!", they seem to almost shout. The shaping of a lighting cone, its' length and girth, in a technica point of view, is not complicated. It is worthy to pay filters and lenses or solely the shape of the casing of the lamp. The final target is the special effect tha is possible to achieve in any named space. And finally colour. Like the way in which rays of light generate colour, the method of using physical values of the different sources of light that is much alike the natural creation of colours. It is an other principle in which the theoretical underton includes a large portion of knowledge that is solely practical and related to engineering. In this case from the scope of lighting technology concerning the physical properties of different types of lighcreasingly widespread use and the environmenta effects they entail, as well as their effects on the space and the observer that resides in it. This als includes the build of the form and the application of colour filters. We must not forget that colour is also paramount to convey emotions, it can be awakening or calming. Colour determines the perceptio can highlight, hide or entirely change a space. While attempting to understand and replicate the physical properties of sunlight, it must not be forgotten that sunlight is movement. Variability. This light could be affected by geographical, climactic or seasonal factors. Movement causes colour change, perception of form and space. The direc
tion of light, its' intensiveness, exertion, tone tem perature are all impacted by movement. However the movement of sunlight causes its' source to nej, takiej jak fontanny, wodospady czy wreszcie zieleń, co podkreśla jej zmienną nature

Emocje niczego. To z jednej strony podsumowanie, a z drugiej kolejna zasada. Żyjąc w świecie pehym emocii, nie uświadamiamy sobie na co dzień, że światto jest jednym $z$ podstawowych komponentów warunkujacych to uczucia. Solatto ipozytym uczucia, ale pozylwne uczucia, ale naszą kreacia ze negatywne, celowo ken kowane reakcje choc dotyczy to jedynie szczegolnych, wysoce scenograficznych sytuacj Może wydobywać głęboko ukryte emocje, nieuświadomione, czasem umyślnie skrywane. Światto to głownie odczucia, emocje, wibracje przestrzeni, falowanie, drganie przeżywane wewnętrznie w sposób nieświadomy. Jak mówi Herve Descottes - efekt „drgania przestrzeni" osiąga się wtedy, gdy ,nie rozumiesz iluminacji otaczającej cię przestrzeni lecz czujesz się w niej dobrze - zupehnie jakbyś widział z zamkniętym oczami, jakbyś wczuwał się w wibracje

\section{PRZYPISY} 1. Mario Nanni, twórca i projektant oświetlenia we włoskiej firmie
Viabizzuno, sam siebie nazywa projektantem cienia.
${ }^{2}$ Nanni M., La luce chce ho In mente, idea e progetto Mario nanni, 3 Oechslin W., Light: a means of creation between reason and emo-
tion, ,Daidalos, Architektur, Kunst, Kultur", no 27, s.23-38, Gutertion, "Daidalos, Architektur, Kunst, Kultur", no 27, s.23-38, Guter-
sloh 1988 "Martyniuk - Pęczek J, Światta miasta, s. 26, Wyda 2014 Nanni M, llibro for m", viabizzunoeditore 2007
"Le Corbusier, "Vers une architecture/W Stronę architektury", 2012 .

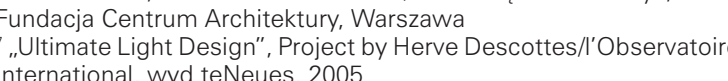

LITERATURA

[1] Nanni M. La luce chce ho In mente, idea e progetto Mario Nanni, wyd. Viabizzuno editore, 2010
[2] Oethslin W., Light:a means of creation between reason and
emotion, ,Daidalos, Architektur, Kunst, Kultur", no 27, s.23-38, Gutersloh 1988 - Pegczek J., Światta miasta, s. 26, Wydawnictwo Ma-
[3] Martyniuk - Pęz 4) Nanni M, Libro for $m$, viabizzunoeditore 2007
5] Le Corbusier, Vers une architecture/ $W$ strone architektury, 2012 .
Fund (6] Weiss S., Matsuoka A M. Ultimate Light Design, Project by Herve
Descottes/'Observatoire International, wyd teNeues, 2005 change. Much alike colour, moving light also plays a role in the field of designing artificial lighting. Despite the similarity here, it is stricly related to architecture, rather a case of ei-

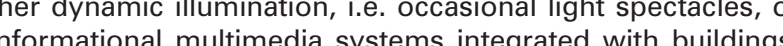
These issues can also be interpreted as the movement of lit matter, such as fountains, waterfalls or finally greenery, that underlines its' various nature.

The emotions of nothing. This is on one side a summary and on the other a final rule. Living in a world full of emotion, we are not aware that every day, light is one of the fundamenta exists. It holds a feeling of safety and positive feelings, but with our adaptation it can also bring out negative ones, it purpose fully directs reactions even though it only applies to individual, highly staged situations. It can bring out deeply hidden emotion, unconscious, sometimes purposefully hidden ones. Ligh is mainly feelings, emotions, the vibrations of a space, wav ing, oscillations experienced internally in a subconscious way achieved when "you do not understand the illumination of the space around you, yet feel good inside it - as though you could see with your eyes closed, as though you could feel the vibrations"

ENDNOTES

Mario Nanni, the creator and the light designer In Italian company Via-
bizzuno, twórca i projektant oswiettenia we whoskiej firmie Viabizzuno, He himsenff is called a a shadow designer. (1) Oechslin W. Light:a means of creation between reason and emotion "Martyniuk - Pẹczek J, S'Swiatta miasta, s. 26. W. Wydawnictwo Marina 2014 "Nanni M, ,libro or m", viabizzunoeditore 2007 ar architektury", 2012, Fundacia Centrum Architektury, Warszawa
",„lltitiate Light Design," Project by Herve Descottes//'Observatoire Inter
national.

BIBLIOGRAPHY

Viabizzun ., edatuce luce chce ho In mente, idea e progetto Mario nanni, wyd. [2] Oechslin W. Light: means of creation between reason and emotion. [3] Martyniuk - Pecczek J., Swiatta miasta, s. 26, Wydawniotwo Marina

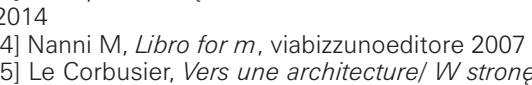

15] Le Corbusier, Vers une architecture/ W strone architekłury, 2012, Fundacia Centrum Architektury, Warszawa
[6] Weigs S.. Matsuok M. Mlltimate Light Design, Project by Herve
Descottes/'Observatoire International, wyd teNeues, 2005 